\title{
What does racial (in)justice sound like? On listening, acoustic violence and the booing of Adam Goodes
}

\section{Poppy de Souza}

Adjunct Research Fellow, Griffith Centre for Social and Cultural Research, Griffith University, Brisbane, Australia

ABSTRACT

At the height of public debate surrounding the sustained booing of Indigenous AFL footballer Adam Goodes between 2013 and 2015, several media commentators routinely misheard the roar of the crowd as nothing other than acceptable social behaviour. To ears invested in the established order, the distinction between a 'boo' and a 'boo' is non-existent; to racialized others, like Adam Goodes, hearing the difference - and calling it out - is an act of resistance, sovereignty, and survival. Taking the booing of Adam Goodes as its starting point, this paper argues for a notion of political listening that attends to the sonic and sonorous histories of racial violence without displacing, or indeed replicating, its wounding effects. I consider the entangled relationship between sound, power and violence, moving beyond the sporting field to examine other acoustic territories where struggles for sovereignty, power and racial justice are playing out. By attending to the ways sound is unevenly deployed to target, silence, assimilate or oppress others along racial lines, this paper hopes to unsettle the listening logic and privileged position of the white, settler-colonial ear, to expose the norms of attention that condition and solidify their appearance. 


\section{The roar of the crowd}

At the height of public debate in August 2015 around the sustained booing of Adnyamathanha man Adam Goodes - one of the country's most successful Australian Football League (AFL) players, two-time Brownlow Medal winner and 2014 Australian of the Year - there were competing voices and polarized views in the media about whether the crowd's behaviour was, or was not, a display of racism. Goodes had been the target of repeated booing and simmering racial abuse since mid 2013. ${ }^{1}$ By 2015, opposition crowds booed Goodes at all grounds he played at, and were 'particularly unsporting and vehement in Perth' (Judd and Butcher 2016, 76). Somewhat ironically, the booing intensified in the wake of the AFL's annual Indigenous Round, a round in the AFL calendar that celebrates and recognizes Indigenous players and Indigenous culture and which is regularly attended by a crowd of over 80,000 at the MCG (Melbourne Cricket Ground), the largest sporting venue in the country. In that weekend's game, Goodes performed an Aboriginal war cry dance on the field to celebrate a goal. The dance was taught to him by members of the under-16 Flying Boomerangs, the Indigenous AFL youth squad (Goodes cited in Curley 2015) and incorporated moves to reflect the words 'strong', 'fast', 'hunting' as well as the action of throwing a boomerang (Booth and Ahmat 2015). As Goodes described in a press conference the following day, the Indigenous Round was the first opportunity he had to perform the war cry and 'show that passion and that pride about being a Warrior and representing my people and where I come from' (Goodes cited in Curley 2015).

Yet, his expression of cultural pride, leadership and Indigenous sovereignty (Phillips and Klugman 2016, 193) was a predictable lightning rod for criticism in sporting commentary and popular opinion. Larissa Behrendt (2015) expressed bafflement than an expression of Aboriginal culture is seen as 'un-Australian', but as Judd and Butcher $(2016,70)$ have argued, the resultant booing of Goodes and its justification as 'socially acceptable crowd behaviour' occurred precisely because he had 'dared to insert Aboriginal cultural meanings, including Aboriginal understandings of history, into the national game'. Not surprisingly, both high profile media commentator and Collingwood Football Club president Eddie McGuire, and former Victorian Premier and former Hawthorn Football Club president Jeff Kennett, publicly criticized Goodes' act as delib- erately provocative, defending the crowd's behaviour as acceptable. Kennett was unam- biguous in his position: 'this isn't an act of racism; this is an act where many in the community feel as if they've been provoked, and they are responding to that provoca- tion' (ABC Radio National 2015). But as Maxine Beneba Clarke (2016) insists, 'denial is crucial in maintaining the status quo. When you are accustomed to privilege, equality feels like oppression'. By late July, the booing had intensified further and Goodes made the decision to sit out of the following weekend's fixture.

Kennett's public comments denied racism by focusing attention back on Goodes, de- politicizing the booing by likening the sporting field to a modern-day Colosseum (ABC Radio National 2015). His analogy of football-field-as-sporting-Colosseum plays on an established tradition of sledging and verbal abuse in sport, where booing players on the opposing team is understood as an everyday, acceptable part of the game; a part of the theatricality of the sport. Following Kennett's performative logic, provocation of the crowd - intentional or otherwise - both solicits and deserves a hostile response. Setting aside the problem with this logic for the moment, Kennett's Colosseum analogy touches on a deeper, troubling, truth. In the popular imagination at least, the roar of the crowd is the sonic barometer that measures who is accepted and who is rejected; who belongs and who is banished; who is loved and who is hated. In other words, the Colosseum is an acoustic territory of unevenly distributed power and populism, with the sound of violence at its very heart.

How, then, do we make sense of the refusal to hear racism in the crowd's booing of Adam Goodes, as epitomized in the comments of Kennett and others? I propose that the failure to register anything other than acceptable crowd behaviour is not so much an inability to hear than a wilful mishearing conditioned through, and which naturalizes, the privileged position of 'white ears'. These white ears wilfully mishear the long history of racial abuse directed against Aboriginal players in the history of the AFL; they also erase previous acts of aboriginal resistance, sovereignty and leadership in the face of such abuse. ${ }^{2}$ This leads me to a second, related, contention - namely that the discourse of 'hurt feelings' is increasingly hollowed out and redeployed to dismiss claims of racism. For example, former non-Indigenous AFL player Jason Akermanis publicly accused Goodes of being a 'sook' and 'playing the victim' (AAP/ABC 2015) in response to his temporary withdrawal from the game. This accusation simultaneously dismisses the serious wounding caused by racial violence at the same time as reproducing and perpetuating its 
logic. Through the narrow focus on individual fragility, hurt feelings are untethered from the broader category of moral injury to which they belong. Shifting the focus from individual fragility onto the ways in which the denial of dignity, respect and justice occur is crucial to understanding how structures of racism are articulated in everyday life.

As a category of moral injury, hurt feelings are a relational, inter-subjective harm: it is hard to envisage how one could hurt one's own feelings, for instance. The concept of moral injury connects to notions in critical theory and moral philosophy around mis- recognition, disrespect and injustice (Bernstein 2005; see also Fraser and Honneth 2003). The wilful mishearing of hurt feelings as individual fragility (rather than as moral injury) both displaces the harm from one conditioned through unequal social relations to one that arises from the individual experience alone, and at the same time, diminishes its scale and depth. By insisting that hurt feelings as a form of moral injury, we can see how they may arise through differences in power and privilege, including acts that press those differences onto others.

From these initial provocations, the following questions arise: how do established hierarchies of attention (Dreher 2009) and dominant listening practices mishear the serious moral injuries of racial abuse? How do they reinforce systems of oppression and the privilege of whiteness? And how can claims of racial injustice be heard and taken seriously without reducing the discussion to an issue of free speech, or in this case, 'the freedom to boo'?

This article takes up some of these questions by arguing for an expanded notion of 'political listening' (Bickford 1996) that attends to the sonic histories of racism as a way of unsettling the listening logic and privileged position of the white ear. For Bickford $(1996,129)$, oppression works, in part, through 'not hearing certain kinds of expressions from certain kinds of people'. Her notion of political listening both challenges the valorization of speech and asserts a charge of ethical responsibility to others: 'just as speakers must reflect on how to speak (and what to say), listeners must be self-conscious about how they listen (and what they hear) (129)'. Similarly, Tanja Dreher (2009) argues that political listening is crucial in shifting focus onto the conventions, hierarchies and discourses which shape not only what is and is not heard and valued but also who is and is not heard.

I suggest that by further extending the notion of political listening to include attention to sound and the sonic register of racial injustice, it becomes possible to push beyond predictable rights-based arguments that privilege freedom of speech as well as liberal discourses of tolerance or diversity. Making this move opens up space for me to register these very particular and distinct kinds of moral injury without displacing, or replicating, their wounding effects. It allows me to pose the critical question: what does racial (in)justice sound like?

In the next section, I briefly turn to the public debate and media commentary around issues of free speech and racial vilification legislation to place the booing of Adam Goodes in the broader context of contemporary race politics in Australia. I then introduce the notions of acoustic violence and the listening ear as analytical tools for political listening. In the second half of the paper, I follow the sounds of racialized violence beyond the football field to other acoustic territories to map overlapping struggles where questions of race, sovereignty and power play out. I examine the use of sonic warfare in the occupied West Bank, before moving in later sections the sounds of racial injustice in the United States. I return in the final section to Goodes and the football field, and conclude by reflecting on the decision by Yorta Yorta woman, soprano Deborah Cheetham not to sing the national anthem at the 2015 AFL grand final.

\section{Listening, speech and the ear of the law}

Proposed changes to Section 18C of the Commonwealth of Australia (1975) (the Act) in 2011, and renewed pressure to amend the Act by conservative Senators David Leyonhjelm and Cory Bernardi in early 2017, have oriented public discussion towards the appropriate limits (if any) on the rights of individuals and freedom of speech. Such discussions underplay the serious and disproportionate negative impacts particular speech acts have on racial and ethnic minorities while claiming they limit the rights of others to free expression. 
Contrary to the popular prevailing view that the Act makes it unlawful to offend someone on the basis of their race, ethnicity or religion, Section 18D of the Act provides a number of exemptions which makes some forms of speech legally permissible - including racial vilification - within certain limits: speech uttered 'in good faith', of 'genuine belief', 'reasonably' and in a 'fair' manner is protected (Commonwealth of Australia 1975, Section 18D). What is interesting here is that the 18D exemption opens a sonorous space attuned to both tone and mode of address in determining whether a particular speech act falls within the boundaries of lawful speech. It connects speech to ethical behaviour and injurious speech to the exercise of power; it also pays close attention not only to what is said, but how it is said and to what effect. In other words, 18D constitutes a space of attention between the intention (of speech) and intensity (of affect) in determining what speech means and what speech does.

In 2011, prompted in part by the Federal Court's upholding of a high-profile case successfully brought against conservative commentator Andrew Bolt under by nine Aboriginal applicants under Section 18C of the RDA, the then Abbott-led federal government proposed a series of amendments to Sections 18C and 18D of the Act. The subsequent exposure draft sought to remove the words 'offend', 'insult' and 'humiliate' from section 18C, along with the words 'reasonably' and 'in good faith' from Section 18D. ${ }^{3}$ These two amendments in particular expose the hierarchies of attention that structure the ear of the law in determining what counts as unlawful speech under the Act. At the time, the Attorney-General Senator George Brandis - the highest ear of the law in parliament - argued the words offend, insult and humiliate 'describe what has sometimes been called hurt feelings' (ABC Radio National 2015; italics mine). This listening logic is the same logic behind Akermanis' comments about Goodes being a 'sook' and 'playing the victim' described earlier. Framing the impacts of racial abuse in terms of hurt feelings alone is a wilful mishearing of moral injury that reinforces white privilege. When then Senator Nova Peris, the first female Indigenous federal member of Parliament, asked about the government's plans to amend the Act, Attorney General Brandis' responded that 'people have a right to be bigots' (Commonwealth of Australia 2014).

In a second attempt to change the legislation in March 2017, the Turnbull government proposed to remove the words 'offend,' 'insult' and 'humiliate', this time replacing them with the words 'harass' and 'intimidate'. The bill was ultimately defeated in the Senate. Despite these unsuccessful attempts to change the legislation, what becomes clear is that it is precisely those sections of the Act that require attention to the affective qualities of a speech act or utterance that are the most problematic for conservative critics. The con- certed push to remove the word 'humiliate' from Section 18C (in both the 2011 exposure draft and the 2017 proposed amendments) also seems particularly significant, despite the claim that many see it as merely 'an operatic outbreak of gesture politics' (Murphy 2017) on the part of the Government. Wiradjuri man, journalist Stan Grant (2016) has described Indigenous people's shared recognition of the 'howl of humiliation' at work in the boos targeted at Adam Goodes, a settler-colonial form of violence that works through the deployment of sound. It is clear that humiliation has a sound that carried through history, borne by those who bear the wounds of that history. The claim that Aboriginal people are 'too sensitive' does not account for ongoing colonialisms, oppression and dispossession that produce such howls of humiliation in the first place.

Another challenge when thinking about the booing aimed at Goodes is that while booing is a speech act, it is an utterance that denies a reduction to words. This is part of the reason why it can neither be defended nor fully understood through recourse to ideas of freedom of speech (on the one hand) or cultural diversity and tolerance (on the other) alone. It is worth noting also that booing is a particular kind of utterance that has a series of perlocutionary effects. A boo is a transitive utterance; it is directed at an object. In other words, it is an utterance with direction - it moves. However, the injury it can perform is not a simple case of cause and effect. As Butler $(1996,204)$ asks:

[...] is it the utterance or the utterer who is the cause of the injury, or does the utterance perform its injury through a transitivity that cannot be reduced to a causal or intentional process originating in a single subject?

What Butler makes clear is that intentionality and causation are not always necessary for wounding to occur, and their relationship is far from straightforward. It carries both direction and movement towards its target, asserting a charge that is not always clear or unambiguous but which generally communicates disapproval or displeasure. Focussing on the intention of the crowd or a single 'booer' alone fails to account for the ways that booing gains both its force and power to inflict moral injury as a collective, yet 
dispersed, utterance that is amplified and intensified as it circulates through the crowd, increasing the acoustic violence. Sounds come from somewhere; they have a history. Individuals who are 'swept up' with the crowd are also entangled in this larger history (recall the 13-year-old girl who was unaware that calling Adam Goodes an 'ape' was racist or was historically used as a racial epithet). However, the utterance also has a sound. The force of the word is always also a sonic force: the sheer sound of it as it echoes through the body politic.

\section{The listening ear}

There was one passing mention in print about the fact that Goodes had played over 300 football games and had enough experience to gauge the mood - or tone - of the crowd and therefore able to distinguish between standard rowdy behaviour and racially motivated verbal abuse. Yet, this aspect of racism - its particular sonorous and sonic quality, and the wounding that it causes - was noticeably absent from public debate and remains critically under-examined. One notable exception was academic and broadcaster Waleed Aly (2015) whose comments provide a sonic entry point into the analysis of racial injustice and violence:

Anyone listening to those boos who is familiar with the dynamics of racism can hear it in the boos. There's a certain quality to them. There's something about it that sounds markedly different from the other boos that players get (italics my own).

What Aly identifies is what I am calling the acoustic violence of racism. Federico Miyara (1999) has described acoustic violence as 'violence exercised by means of sound', where violence involves either force or threat of force causing damage, unrest, hurt or harm. Significantly, he adds that it can also cause 'unease, discomfort and helplessness', under certain conditions, regardless of intention. As an expression of power, acoustic violence carries with it the possibility for both moral and political injury. Thinking about the booing of Adam Goodes in terms of acoustic violence brings into view the ways in which racism creates a hostile sensory terrain that certain populations and individuals must navigate on a daily basis. These sounds, then, embody far more than what is at first apparent to the untrained ear.

In the above quote, Aly stops short of unpacking the precise quality and dynamics that make some boos distinct from others. Yet his insistence on the distinction - and their uneven distribution along racial lines - warrants serious consideration. At the heart of his critique lies an important observation, perhaps drawn from his embodied experi- ence: those who are the targets of racialized violence become attuned to sonic qualities that are indistinct to untrained ears. In this, there are two points. First, to distinguish between a 'boo' and a 'boo', a particular structure of intelligibility is required (following Butler 2009). In Aly's formulation, a precondition for hearing racism is an already present familiarity (a pre-disposition perhaps?) with the dynamics of racism. The distinction between a 'boo' and a 'boo' may be altogether absent to the untrained ear, but to those exposed to its injurious effects, parsing this distinction can be a challenge against ongoing injustice and, in some cases a necessary act of survival, as I discuss further on. Second, the repeated exposure to racialized violence produces expert listeners attuned to the sounds of that violence. In other words, it is their very exposure that marks out as expert listeners; they are ears trained to hear racism.

In her illuminating examination of sound, race and the cultural politics of listening in the United States, Jennifer Stoever (2016) exposes the systems that produce and regulate cultural ideas about sound to theorize what she calls the 'sonic color line' (13). Focused on the history of African American music and literature in particular, she explores listening as 'a form of agency, a technique of survival, ethics of community building, practice of self- care, guide through racialized space, site of racialisation and mode of decolonising' (17). Central to her analysis are the contrasting figures of the 'listening ear' and the 'embodied ear', concepts useful to my own acoustic analysis. For Stoever, the listening ear is

[...] a figure for how dominant listening practices accrue - and change - over time, as well as a description for how dominant culture exerts pressure on individual listening practices to conform the sonic color line's norms (7).

In contrast, the embodied ear represents how 
[...] individual listening practices are shaped by the totality of their experiences, their historical context, and physicality, as well as intersecting subject positions and particular interactions with power (the listening ear) (15).

This tension and interplay between the listening ear and the embodied ear reveals how established hierarchies of attention are produced and maintained through a continued investment in the values, norms, practices - and sounds - of the dominant culture. Listening practices attuned to racialized histories of sound and, relatedly, attention to the way sound can be deployed as a weapon of force, can unsettle the structures of power that condition and normalize their appearance.

\section{Sound and violence}

The relationship between sound and violence has a long and complicated history. Sound has been used as a weapon of force in the exercise of power, dominance and control over individuals and populations, including as a tactic to disarm political dissent. For example, in 2014, Jordanian-British artist and researcher Lawrence Abu Hamdan was approached by Palestinian human rights organization Defense for Children International (DCI) to conduct an acoustic analysis of the sounds of gunfire deployed by members of the Israeli police on a group of unarmed Palestinians in the occupied West Bank that resulted in the death of two Palestinian teenagers, Nadeem Nawara and Mohammad Abu Daher (Defense for Children International 2014). As Abu Hamdan described, the case hinged upon an audio-ballistics analysis of the recorded gunshots to determine whether the soldiers had used rubber bullets, as they claimed, or had 'broken the law by firing live ammunition at the two unarmed teenagers' (Abu Hamdan 2016). Abu Hamdan analysed the sound recordings of the incident, examining both lethal and non-lethal shots fired that day into the crowd. To the untrained ear, the lethal and non-lethal shots sound identical. However, spectrogram analysis - a form of analysis which visualizes and strands out different frequencies of a noise - revealed a distinct difference between the sound signature of live ammunition as compared to ammunition fired through a rubber bullet extension. ${ }^{4}$

When Abu Hamdan synced up the CNN news footage of the incident to the audio recording of the gunfire, it was evident the Palestinian crowd reacted in dramatically different ways to the rounds of live ammunition than they did to shots fired through a (non-lethal) rubber bullet extension, rapidly dispersing to seek shelter only when live shots were fired. From this, Abu Hamdan concluded that for this group of Palestinian civilians, constant exposure to this kind of 'sonic warfare' (Goodman 2010) marked them out as expert listeners able to distinguish between the sonic characteristics of live gunfire and gunfire masked with a rubber bullet extension, something that sounds identical to the untrained ear but could be visualized through spectrogram analysis. In his video installation Rubber Coated Steel (2016), which built on the work Abu Hamdan did for DCI, the sonic signature of the killings stands as another form of public testimony: they 'do not preside over the voices of the victims', but rather seek to 'amplify their silence' (Abu Hamdan 2016). He insists:

It is the sound that needs to enter our acoustic consciousness, because in all cases across the world it is the sound where the tools of institutional violence cross the threshold into acts of wanton bloodshed.

How might the example of sonic warfare in the Middle East help us think through the ways that sound and violence can work to dominate and regulate the lives of racialized others more broadly? What can it tell us about the ways individuals and communities routinely targeted become finely attuned to the practices and tactics used to achieve this? In the above case of sonic warfare, the stakes are a matter of life and death. This may seem far removed from the sonic sites of racial injustice and expressions of everyday racism I'm thinking through in this paper. However, I suggest their difference is a matter of degree, not of kind.

\section{Hearing racism}

In his 2016 Quarterly Essay, 'The Australian Dream: Blood, history and becoming', Stan Grant makes an unequivocal connection between the racist booing targeted at Adam Goodes on the football ground and the legacy of settler-colonial violence and Indigenous dispossession: 
I can't speak for what lay in the hearts of the people who booed Adam Goodes. But I can tell you what we heard when we heard those boos. We heard a sound that was very familiar to us. We heard a howl. We heard a howl of humiliation that echoes across two centuries of dispossession, injustice, suffering and survival. We heard the howl of the Australian Dream, and it said to us again: you're not welcome.

Grant's account pushes further than Aly's distinction between a 'boo' and a 'boo'. The 'howl of humiliation' is at once a political metaphor and an embodied response to a particular register of settlercolonial violence directed at First Nations peoples, one that re-appears, circulates and is expressed in different forms. Indigenous people navigate racialized sonic space where the white ear marks out the sonic boundary between belonging and non- belonging (or un-belonging), inclusion and exclusion; where words and sounds perform another kind of dispossession and displacement. At the same time, the boos directed at Goodes are but one articulation of the howl of humiliation, intimately entangled with a larger history of racial injustice that condition their appearance.

Ahmed $(2017,61)$ reminds us that, for many people of colour who experience and are the target of racism and humiliation, 'to remember violence is to bring the sound of violence into the present' (my italics). Ahmed illustrates this point by citing Audre Lorde, whose activist writings and poetry critique the workings of power and privilege in the construction of race, sex, and gender. Lorde recounts a particular sound she was repeatedly exposed to as a child:

As a very little girl, I remember shrinking from a particular sound, a hoarsely sharp, guttural rasp, because it often meant a nasty glob of grey spittle on my coat or shoes an instant later. My mother wiped it off with little pieces of newspaper she always carried in her purse. Sometimes she fussed about low-class people who had no better sense or manners than to spit into the wind no matter where they went, impressing upon me that this humiliation was totally random [...] But it was so typical of my mother when I was young that if she couldn't stop white people spitting on her children because they were Black, she would insist it was something else (Lorde, cited in Ahmed 2017).

I quote from this passage at length because it powerfully highlights the intimate entanglement between acts of racism and their visceral, embodied and sonorous qualities. The sound of being spat on as a child that 'hoarsely sharp, guttural rasp' - carries with it the memory of humiliation. The sound of the rasp is the sonic cue for the child Audre to shrink away in bodily anticipation of what comes next. It is not the spit alone, but the very sound of the utterance, that sharpens her humiliation. The spit travels onto the body of the child Audre, but the sound of the spit collapses both space and time, wrenching up a larger history where the sounds of hate carry meanings and power connected to white supremacy and racial dominance. If we return to Grant's words reflected through Lorde's account above, it becomes clear that the 'howls of humilia- tion' - whether the boo of the crowd or the sound of spit - cannot be disentangled from the violent histories that condition their very appearance.

Critically attending to these sites of acoustic violence - following the sounds - opens up a route to examine other racialized sonic spaces, not with the aim of comparison, but rather to bring into view how the force of sound is used to humiliate, exclude and to put racialized others in their 'place'.

When American tennis player Serena Williams described her experience of being booed and taunted by the crowd at the 2001 Indian Wells tennis tournament in California, she spoke of the undercurrent of racism and the pain it caused her (Williams 2015b). Both Serena and her sister Venus have been subject to hostile crowds and racial taunts for years, most dramatically at the 2001 Indian Wells ${ }^{5}$ final, after Venus had defaulted to Serena in the semi-final to the great displeasure of the largely white crowd in a predominantly white sport. Both sisters subsequently boycotted the tourna- ment for over a decade, with Serena only returning to the tournament in 2014. In 2015, Serena Williams wrote a piece in Time magazine about her experience at the 2001 final:

As I walked out onto the court, the crowd immediately started jeering and booing [...] The undercurrent of racism was painful, confusing and unfair. In a game I loved with all my heart, at one of my most cherished tournaments, I suddenly felt unwelcome, alone and afraid. [. . . ] When I was booed at Indian Wells - by what seemed like the whole world - my voice of doubt became real. I didn't understand what was going on in that moment. But worse, I had no desire to even win. It happened very quickly. This haunted me for a long time. 
Williams' account of simultaneous non-belonging, isolation and fear must be taken seriously to fully register the dynamics of racism beyond racial epithets and speech acts alone. In the above excerpt, it is clear that the booing and racial abuse had multiple and complicated effects for Williams. First, the sounds of jeering and booing were 'confusing' and disorientating: she did not understand what was going on. Second, and echoing the quote from Grant (2016) cited earlier, the booing made her feel 'unwelcome', rupturing her sense of belonging by sonically marking out a space of difference; they were a threatening form of exclusion, making her feel 'alone' and 'afraid'. Third, they were a haunting.

Attempts to justify or defend the crowd's behaviour by citing the Williams' sisters' bad sportsmanship - a justification also used by some to defend the booing of Goodes - does not account for the repeated and disproportionate booing Williams has been subject to throughout her career, and the expectation that she conform to the stereo- type of the 'exceptional black athlete' by suffering racial abuse graciously and without complaint. While Williams is not immune to the injurious and exclusionary effects of this repeated sonic violence, like Goodes, she too refuses to let them go unchallenged.

Poet and cultural critic Claudia Rankine (2015) argues that while Williams has dis- carded the white racist gaze, it 'doesn't mean she won't be emotional or hurt by challenges to her humanity'. It is precisely in her refusal that her grace and excellence is demonstrated:

Serena's grace comes because she won't be forced into stillness; she won't accept those racist projections onto her body without speaking back; she won't go gently into the white light of victory. Her excellence doesn't mask the struggle it takes to achieve each win. For black people, there is an unspoken script that demands the humble absorption of racist assaults, no matter the scale, because whites need to believe that it's no big deal. But Serena refuses to keep to that script. Somehow, along the way, she made a decision to be excellent while still being Serena.

Challenging racism for athletes like Williams and Goodes involves putting their bodies on the line, refusing to absorb racist insults by challenging their very legitimacy and disrupting the norms of whiteness that make such assaults acceptable. They dismantle the 'unspoken script'. They hear racism and call it out; unsettling and challenging otherwise socially acceptable or normalized behaviours (in some cases, celebrated behaviours like the booing of one's opponent) by insisting such behaviour cannot be separated from histories and practices of racism. The sporting field, the tennis court, and so forth, are not spaces quarantined from history, culture and politics. To not hear racism in booing of Goodes and Williams is a refusal to hear the testimony of racialized others, and a denial of voice. It is made possible through what Cate Thill (2009) calls 'selective listening' which functions to 'preserve, rather than transform, established hierarchies of attention'.

Goodes' temporary withdrawal from the game in August 2015, his decision not to speak, was significant. Taking time to spend with his family, to be on Country, ${ }^{6}$ Goodes also removed himself from the media storm that was swirling around him. His dignified public silence in the face of intense media scrutiny brings to mind the words of Butler 2009, 12) who argues the 'refusal to narrate' can 'call into question the legitimacy of authority' by attempting to circumscribe a 'domain of autonomy' for the subject. In this sense, silence becomes a defiant act of self-relation that asserts itself through a with- drawal from established terms and frames of recognition and legitimacy, in this case, from the competing and conflicting demands of the public and the media pressing down on him for a response. More broadly, this 'politics of refusal' (Bond 2016) shifts the very terms and frames of the debate. Goode's silence - his absent-presence - invites us to reflect on other silences that deny Indigenous sovereignty and consolidate settler- colonial power: 'the Great Australian Silence' (Stanner 1969); and, more recently, 'the silence at the heart of the Constitution' (Williams 2015a, 121).

\section{Voice, silence and resistance}

What forms of resistance and healing does silence make possible? What nuances, strategic forms of engagement and ways of navigating or resisting power are made possible through silence? What alliances might be enabled as we learn to read [or hear] silences? Under what conditions is it productive to move between voice and silence? Rowe and Malhotra 2013, 7). 
In this final section, I turn to another acoustic territory where the struggle against racial injustice takes centre stage, and is staged, in several ways. In the months following the booing of Goodes, Deborah Cheetham, an internationally renowned soprano, was invited by the AFL to sing the Australian national anthem at the 2015 Grand Final. In response to this invitation, Cheetham proposed she sing the anthem with amended lyrics, replacing the line 'for we are young and free' with 'in peace and harmony'. ${ }^{7}$ After some consideration, AFL management found they could not support her proposal and she graciously declined to perform. In a subsequent article written for The Conversation, Cheetham (2015) explained her reasons:

As an Indigenous leader I simply can no longer sing the words 'we are young and free'. For that matter, as an Australian with a strong desire to deepen our nation's understanding of identity and our place in the world, I believe we can and must do better.

To be asked to sing in front of a live audience of tens of thousands of people and sing the national anthem is, in Cheetham's (2015) words, 'every performer's dream'. By declining to sing, Cheetham performs a political act of leadership and resistance that unsettles the nation's complacency about ongoing injustice. Her decision not to sing questions the legitimacy of the anthem and its role in perpetuating a settlercolonial narrative of the nation. Cheetham is a highly respected Indigenous public figure and soprano. As an Indigenous leader, Cheetham spoke to the ways in which the anthem is both hurtful to and excludes Indigenous people. As a soprano - whose very instrument of expression is her voice - to choose silence over sound is a powerful act of both resistance and hope. Cheetham enacts leadership by challenging the white ear that naturalizes the national anthem as benign and patriotic. In hearing the logic of white possession (Moreton-Robinson 2004) in the anthem's lyrics, Cheetham's enacts Indigenous sovereignty through performative silence.

As an expert listener - both in a musical sense and in the sense of racialized attunement I have been describing - Cheetham draws attention to how the national anthem operates as a form of sonic dominance that perpetuates a settler-colonial narrative of terra nullius and legitimates the founding myth of the nation state. If singing the anthem performs a kind of acoustic violence, the lyrics recite a narrative violence that both denies Indigenous sovereignty and fails to recognize Australian history prior to 1788 . Predictably, there was anger in some sections of mainstream and social media in response to Cheetham's decision not to sing the anthem. ${ }^{8}$ However, in an interview $\mathrm{ABC}$ radio, she spoke about how singing the anthem with the current lyrics also deeply affects many Indigenous people: "how hurtful it is to Indigenous Australians to really be excluded, because when we sing that "we are young" in that anthem, that really does set up a false premise'. To yield to Cheetham's authority as an expert listener attuned to the sonic traces of racial injustice opens a space of both democratic and sonic disso- nance - the lyrics

don't ring true. Cheetham's performative silence insists we ask a broader question: how might we register Indigenous claims to sovereignty, beyond legal or constitutional forms of recognition alone? ${ }^{9}$

\section{Conclusion: what would justice sound like?}

By attending to the ways sound is unevenly deployed to target, silence, assimilate or oppress others along racial lines, this paper has ultimately aimed to unsettle the listening logic and privileged position of the white, settler-colonial ear, in Australia and beyond. If political listening asserts a charge of responsibility towards others in the pursuit of more just and equitable futures, it must also refuse listening positions that solidify forms of settler-colonial power or reproduce ongoing colonialisms. In taking up sound as frame of analysis, I have argued for an expanded notion of political listening that attends to the sonic histories of racialized violence, but which also registers acts of sovereignty, resistance and hope in the face of ongoing injustice. Not only is this move analytically useful, opening fresh lines of 'sonic' inquiry which bring into conversation the struggles of those whose lands and life-worlds continued to be structured by colonial and imperial logics; it is also politically necessary to 're-sound' the public sphere (Lacey 2011, 9) and, in turn, pose the critical question: what would justice sound like? 
1. In May 2013, Goodes was called an 'ape' by a 13-year-old girl in the crowd at a game between the Sydney Swans and Collingwood.

2. For example, Nicky Winmar and Michael Long in the 1990s and early 2000s, respectively.

3. Bolt was found to have breached the Act for a series of articles he wrote which claimed certain Aboriginal people sought professional advantage from being 'fair-skinned' (see Federal Court of Australia 2011). The Court ruled Bolt was in breach of the Act and not exempt under section 18(D), which pertains to fair comment in the matter of public interest, because of his failure to act 'in good faith', along with errors of fact in his claims.

4. Abu Hamdan's video analysis of the shooting, including the audio-ballistics and spectro- gram analysis, can be accessed here: http://lawrenceabuhamdan.com/blog/2014/11/21/preview-to-my-audio-balisticsinvestigation-into-the-murder-of-nadeem-nawara

5. Itisworthnotingthelandonwhichthistournamentisplayed,IndianWellsinCalifornia,US, is a site of First Nations dispossession and colonization brought about by the arrival settler explorers and gold prospectors to the area in the nineteenth century that devastated the Indigenous population.

6. In Australia, the term Country has a specific meaning for Indigenous people and is incommensurable to nonIndigenous or geo-political definitions of country/land/territory (see Moreton-Robinson 2004). Indigenous people's ontological connection to Country describes their spiritual, physical, social and cultural attachment and sense of belonging to their ancestral lands.

7. Cheetham later pointed to alternative lyrics to the Anthem - penned by Judith Durham in consultation with Muti Muti singer-songwriter Kutcha Edwards - that include and celebrate the history and culture of First Nations Australians, as a starting point for a broader public conversation around settler-Indigenous relations.

8. A similar level of anger was directed at boxer Anthony Mundine when he declared he would not come out when the national anthem was played at the start of his fight, saying 'we are not young and free ... my people are still being oppressed' (Herald 2017). A similar point has been made by Stan Grant (2016). In 2016, African American football player Colin Kaepernick sat down or knelt, rather than stood, when the US national anthem was played, to draw attention to police brutality and racial injustice in that country.

9. It is interesting that mainstream media receptions of the 'Uluru Statement from the Heart' - arising from the First Nations National Constitutional Convention - were negatively framed as a 'refusal' of recognition, rather than the need for a First Nations Voice and a desire to 'be heard'. This invitation to listen insists Indigenous sovereignty be placed at the heart of healing injustice.

\section{References}

AAP/ABC. 2015. "Adam Goodes Playing the Victim over Booing, Says Former AFL Star Jason Akermanis.” ABC News Online, July 31. Accessed 10 October 2016. http://www.abc.net.au/ news/2015-07-30/jason-akermanis-says-adamgoodes-is-a-sook/6659344

ABC Radio National. 2015. “Jeff Kennett on Bishop and Goodes.” RN Drive, July 30. Accessed 29 March 2017. http://www.abc.net.au/radionational/programs/drive/kennett-on-bishop-and- goodes/6661120

Abu Hamdan, L. 2016. Earshot. Exhibition notes. http://lawrenceabuhamdan.com/new-page-1/ Ahmed, S. 2017. Living a Feminist Life. Durham and London: Duke University Press.

Aly, W. 2015. "Racism and Adam Goodes." The Minefield. ABC Radio National, July 30. Accessed 6 August 2015. http://www.abc.net.au/radionational/programs/theminefield/racism/6656974.

Behrendt, L. 2015. "The Backlash against Adam Goodes Is the Reason His War Dance Is Important." The Guardian, June 1. Accessed 29 March 2017. http://www.theguardian.com/commentisfree/

2015/jun/01/the-backlash-against-adam-goodes-is-the-reason-his-war-dance-is-important.

Bernstein, J. 2005. “Suffering Injustice: Misrecognition as Moral Injury in Critical Theory.” International Journal of Philosophical Studies 13 (3): 303-324. doi:10.1080/09672550500169117. 
What does Racial (In)justice sound like? On listening, acoustic violence and the booing of Adam Goodes

Bickford, S. 1996. The Dissonance of Democracy: Listening, Conflict, and Citizenship. Ithaca and

London: Cornell University Press.

Bond, C. 2016. "Refusing to Play the Race Game." The Conversation, 29 September. Accessed 6 April 2017. https://theconversation.com/refusing-to-play-the-race-game-66043

Booth, A., and N. Ahmat. 2015. "That Adam Goodes War Cry Used a Boomerang Not a Spear: Choreographer." NITV News. SBS. Accessed 18 September 2017. http://www.sbs.com.au/nitv/article/2015/08/03/adam-goodes-war-cryused-boomerang-not-spear-choreographer.

Butler, J. 1996. “Burning Acts: Injurious Speech.” The University of Chicago Law School.

Butler, J. 2009. Frames of War: When Is Life Grievable? London: Verso Books.

Cheetham, D. 2015. "Young and Free? Why I Declined to Sing the National Anthem at the 2015 AFL Grand Final." The Conversation, October 20. https://theconversation.com/young-and-free-why-i-declined-to-sing-the-nationalanthem-at-the-2015-afl-grand-final-49234

Clarke, M. B. 2016. “Our Unnamed Racism Holds Us Back.” The Monthly, August 13. https://www.

thesaturdaypaper.com.au/opinion/topic/2016/08/13/our-unnamed-racism-holds-us-back/14710104003607

Commonwealth of Australia. 1975. Racial Discrimination Act (RDA). Consolidated, Accessed January 2014. https://www.legislation.gov.au/Details/C2014C00014

Commonwealth of Australia. Parliamentary Debates. 2014. “The Senate. Questions without Notice:

Racial Disrimination Act." (Hansard) March 24: 1797-1798. doi: 10.1101/gr.176784.114

Curley, A. 2015. “Proud Goodes Stands by War Cry Celebration.” AFL News, May 30. Accessed 6 May 2017. http://www.afl.com.au/news/2015-05-30/proud-goodes-stands-by-war-cry-celebration

Defense for Children International. 2014. "Israeli Forces Shoot and Kill Two Palestinian Teens near Ramallah." May 17. http://www.dci-palestine.org/israeli forces shoot and kill two palestinian teens near ramallah.

Dreher, T. 2009. "Listening across Difference: Media and Multiculturalism beyond the Politics of Voice." Continuum 23 (4): 445-458. doi:10.1080/10304310903015712.

Federal Court of Australia. 2011. Eatock V Bolt [2011] FCA 1103. File Number VID 770 of 2010. September 28. Federal Court of Australia.

Fraser, N., and A. Honneth. 2003. Redistribution or Recognition? A Political-Philosophical Exchange. London: Verso.

Goodman, S. 2010. Sonic Warfare: Sound, Affect and the Ecology of Fear. Cambridge, MA: Massachusetts Institute of Technology Press. 
What does Racial (In)justice sound like? On listening, acoustic violence and the booing of Adam Goodes

Grant, S. 2016. “The Australian Dream: Blood, History and Becoming.” Quarterly Essay 64 (1): 1-80. Herald, S. M. 2017. Anthony Mundine Refuses to Acknowledge National Anthem before Danny

Green Fight', 30 January. http://www.smh.com.au/sport/boxing/anthony-mundine-refuses-to-acknowledgenational-anthem-before-danny-green-fight-20170129-gu131n.html

Judd, B., and T. Butcher. 2016. "Beyond Equality: The Place of Aboriginal Culture in the Australian Game of Football." Australian Aboriginal Studies 1: 68-84.

Lacey, K. 2011. "Listening Overlooked: An Audit of Listening as a Category in the Public Sphere." Javnost-The Public 18 (4): 5-20. doi:10.1080/13183222.2011.11009064.

Miyara, F. 1999. “Acoustic Violence: A New Name for an Old Social Pain.” Hearing Rehabilitation Quarterly 24 (1): 18 21.

Moreton-Robinson, A. 2004. "The Possessive Logic of Patriarchal White Sovereignty: The High Court and the Yorta Yorta Decision." Borderlands E-Journal 3 (2).

http://www.borderlands.net.au/vol3no2_2004/moreton_possessive.htm.

Murphy, K. 2017. “Coalition's 18C Overhaul a Hollow and Operatic Outbreak of Gesture Politics.” The Guardian, March 21. Accessed 28 March 2017. http://www.theguardian.com/australia-news/2017/mar/21/coalitions-18c-overhaula-hollow-and-operatic-outbreak-of-gesture-politics. P

hillips, G., and M. Klugman. 2016. “The Land We Play On: Equality Doesn't Mean Justice.” Griffith REVIEW 53: 185.

Rankine, C. 2015. "The Meaning of Serena Williams. On Tennis and Black Excellence." The New York Times, August 25. Accessed 28 March 2017. https://www.nytimes.com/2015/08/30/magazine/the-meaning-of-serenawilliams.html

Rowe, A. C., and S. Malhotra. 2013. "Still the Silence: Feminist Reflections at the Edges of Sound.” In

Silence, Feminism, Power: Reflections at the Edges of Sound, edited by S. Malhotra and A. C. Rowe, 1-16. London: Palgrave MacMillan.

Stanner, W. E. 1969. After the Dreaming. Black and White Australians: An Anthropologist's View. Boyer Lectures, 1968. Sydney: Australian Broadcasting Corporation.

Stoever, J. L. 2016. “The Sonic Color Line and the Listening Ear.' Introduction.” In The Sonic Color Line: Race and the Cultural Politics of Listening, edited by J. L. Stoever, 1-28. New York: New York University Press.

Thill, C. 2009. "Courageous Listening, Responsibility for the Other and the Northern Territory Intervention." Continuum: Journal of Media \& Cultural Studies 23 (4): 537-548. doi:10.1080/ 10304310903012651.

Williams, G. 2015a. "Recognising Aboriginal and Torres Strait Islander Peoples in the Constitution.” University of Tasmania Law Review 34 (2): 114.

Williams, S. 2015b. “I'm Going Back to Indian Wells.” Time Magazine, February 4, sec. Tennis. Accessed 6 April 2017. http://time.com/3694659/serena-williams-indian-wells/. 